COMPILATION OF GEOHYDROLOGIC DATA COLLECTED AS PART OF THE AREAL APPRAISAL OF GROUND-WATER RESOURCES NEAR BRANSON, MISSOURI

By Jeffrey L. Imes

U.S. GEOLOGICAL SURVEY

Open-File Report 89-401

Prepared in cooperation with the

CITY OF BRANSON and the

MISSOURI DEPARTMENT OF NATURAL RESOURCES,

DIVISION OF ENVIRONMENTAL QUALITY

Rolla, Missouri

1989 


\section{DEPARTMENT OF THE INTERIOR}

MANUEL LUJAN, JR., Secretary

U.S. GEOLOGICAL SURVEY

Dallas L. Peck, Director

For additional information

write to:

District Chief

U.S. Geological Survey

1400 Independence Road

Mail Stop 200

Rolla, Missouri 65401
Copies of this report can be purchased from:

U.S. Geological Survey

Books and Open-File Reports

Federal Center, Bldg. 810

Box 25425

Denver, Colorado 80225 


\section{CONTENTS}

Page

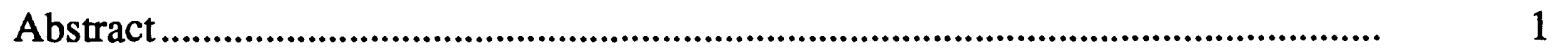

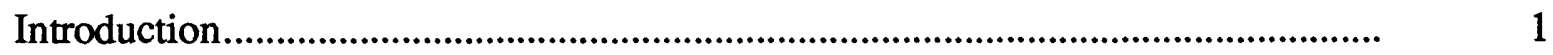

Geohydrologic description of the study area ............................................................. 3

Ground-water levels in the Ozark aquifer..................................................................... 3

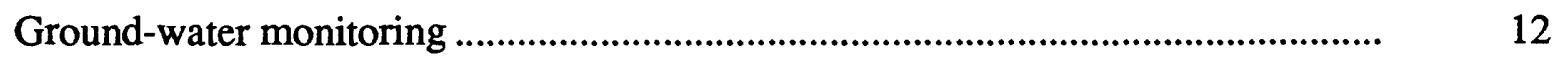

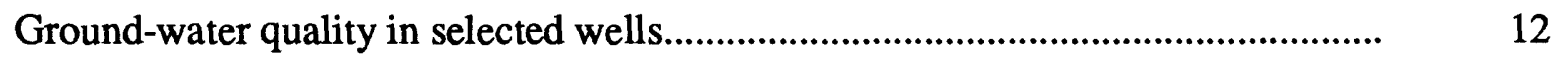

Ground-water use by municipalities, public water-supply districts, and selected businesses.................................................................................................. 12

Ground-water flow model development ............................................................. 23

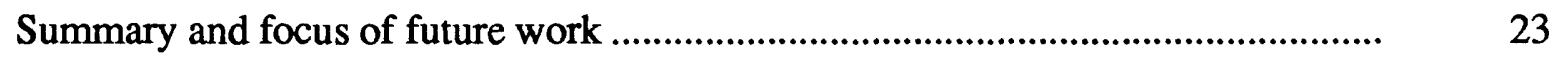

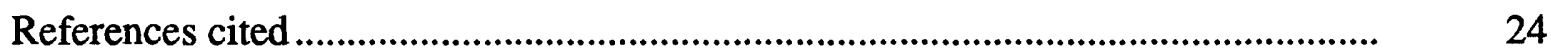




\section{ILLUSTRATIONS}

Page

Figures 1.-6. Maps showing:

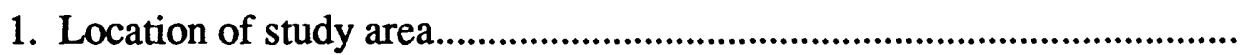

2. Location of wells in which water levels were measured in June and July 1988 and in March 1989.

3. Location of water-level monitoring wells.

4. Hydrograph of water levels in well 125 (city of Branson "Michel" Well).

5. Location of wells in which water-quality samples were collected and analyzed for selected inorganic constituents and volatile organic compounds

6. Location of wells for which monthly ground-water use data have been requested

\section{TABLES}

Table 1. Generalized correlation of stratigraphic to geohydrologic units in the Branson area

2. Water levels measured in selected deep and shallow wells

3. Results of specific conductance measurements, fecal coliform bacteria count, and analyses of water samples for selected inorganic species.

4. Results of laboratory analyses of ground-water samples for presence of volatile organic compounds.

5. Monthly ground-water use by the primary ground-water users in the Branson area. 


\section{CONVERSION FACTORS}

To aid those readers who are interested in the International System of Units (SI), the factors for converting from the inch-pound units used in this report to metric units are given below:

Multiply

inch-pound unit

mile

foot

million gallons per month
By

1.609

0.3048

3,785
To obtain

metric (SI) unit

kilometer

meter

cubic meter

per month 


\title{
COMPILATION OF GEOHYDROLOGIC DATA COLLECTED AS PART OF THE AREAL APPRAISAL OF GROUND-WATER RESOURCES NEAR BRANSON, MISSOURI
}

\author{
By \\ Jeffrey L. Imes
}

\begin{abstract}
A rapidly developing retirement community and tourist industry in the Branson, Missouri area has created an increased demand for potable water, especially in the summer months. The rapid pace of residential and business expansion has created concerns regarding the future ground-water availability and quality. Water levels measured in the Ozark aquifer during the summer of 1988 and March 1989 show water levels increasing in 22 wells, decreasing in 2 wells, and remaining the same in 1 well. The water-level increases ranged from 1 to 111 feet. These measurements and similar measurements during the summer of 1989 will be used to calibrate a three-dimensional model of groand-water flow in the Branson area and estimate the long-term effect of large ground-water withdrawals during the summer tourist season.

A reconnaissance of water quality in 34 wells that are open to the Ozark aquifer shows specific conductance ranging from 347 to 841 microsiemens per centimeter at $25{ }^{\circ}$ Celsius and no fecal coliform bacteria present in any well. Chloride and nitrate concentrations in all wells were well below the Missouri Department of Natural Resources recommended maximum concentrations of $250 \mathrm{mg} / \mathrm{L}$ and $10 \mathrm{mg} / \mathrm{L}$ respectively. Analyses of 5 water samples for 33 volatile organic compounds failed to detect any concentrations in excess of the detection limits.
\end{abstract}

\section{INTRODUCTION}

Because of the increased popularity of the Table Rock Lake area (fig. 1) as a recreation attraction and retirement center, the populations of Taney and Stone counties about doubled from 1960 to 1980 . According to the 1980 census, the population of Taney County was 20,500 and the population of Stone County was 15,600. The population increase is most evident in Branson, a small community located on the shore of Lake Taneycomo about $8 \mathrm{mi}$ (miles) downstream from Table Rock Dam. Although the permanent resident population of Branson only increased by 35 percent from 1960 to 1980 (1,887 to 2,550), the number of business establishments in the city have increased markedly to accommodate the large increase in the number of tourists that visit the area annually. The annual influx of tourists during the warmer summer season exceeds the permanent resident population of the area.

The demand for potable water in the city and surrounding area has increased with the population. The city of Branson recently acquired three additional water-supply wells and several recreational industries have drilled large capacity supply wells. Smaller communities around Branson are experiencing similar increased demands for water. Many shallow wells have been drilled to provide rural residences with water. One consequence of the increased demand for water is a lowering of the potentiometric surface of the Ozark aquifer, the aquifer that supplies almost all of the ground water in the area. Because much of the increased water demand occurs during the summer tourist season, water levels are lowered substantially in the summer and recover during the winter. It is the purpose of this study to determine whether water levels in the Ozark aquifer are recovering fully during winter months when less water is used, or are in a state of continued longterm decline resulting from cumulative effect of the large demand for water during summer months. The 2year cooperative study with the city of Branson and the Missouri Department of Natural Resources, Division of Environmental Quality includes measurement of water levels near Branson during two summer seasons and one winter season. The study will conclude with the construction and calibration of a digital model of ground-water flow in the Branson area and preparation of a comprehensive interpretive report. Because of the boundary condition requirements of the model, the boundaries of the study area are extended beyond the 


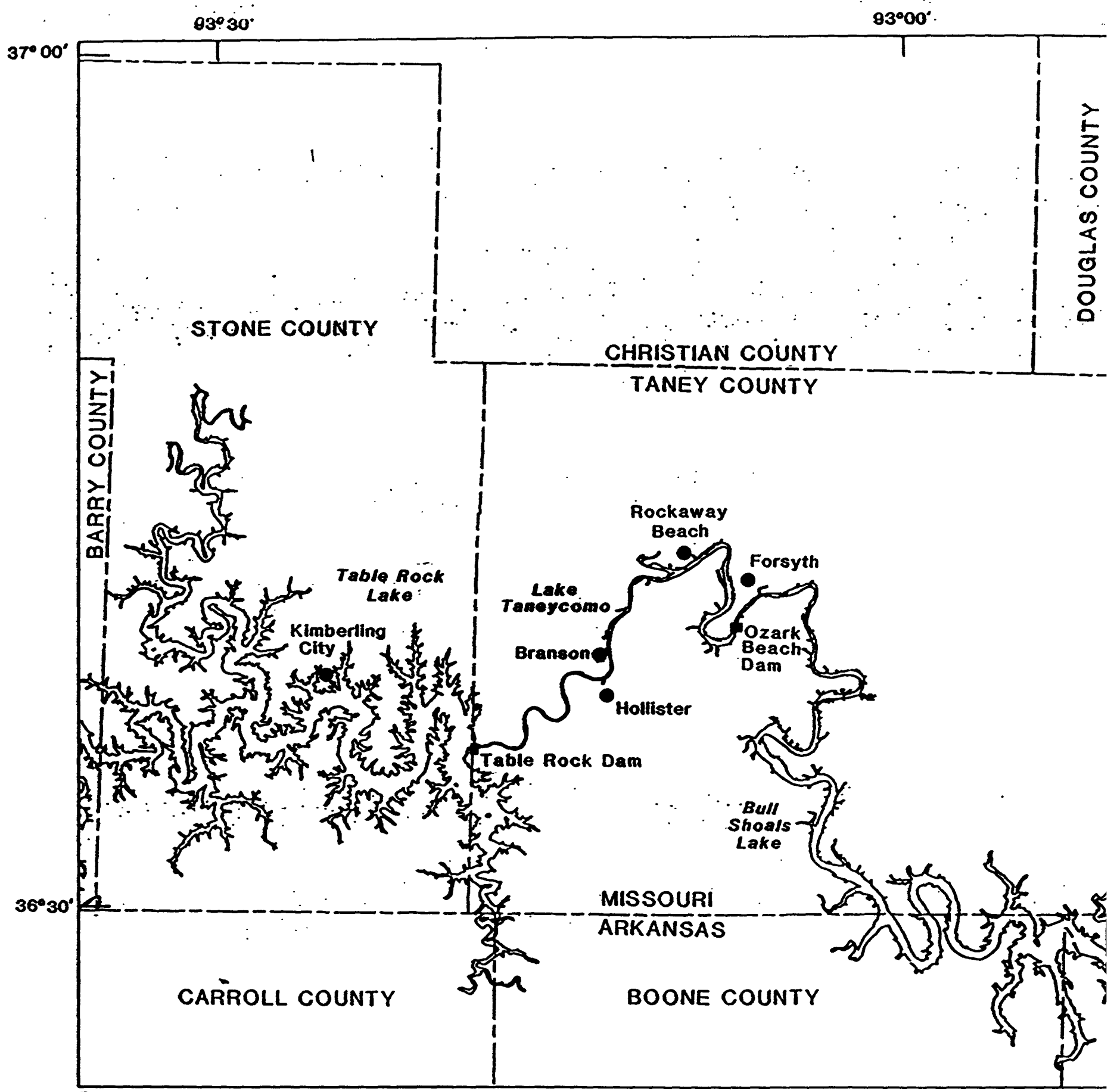

Base from U.S. Geological Survey State

Base map, 1:500,000. Missouri, 1973.
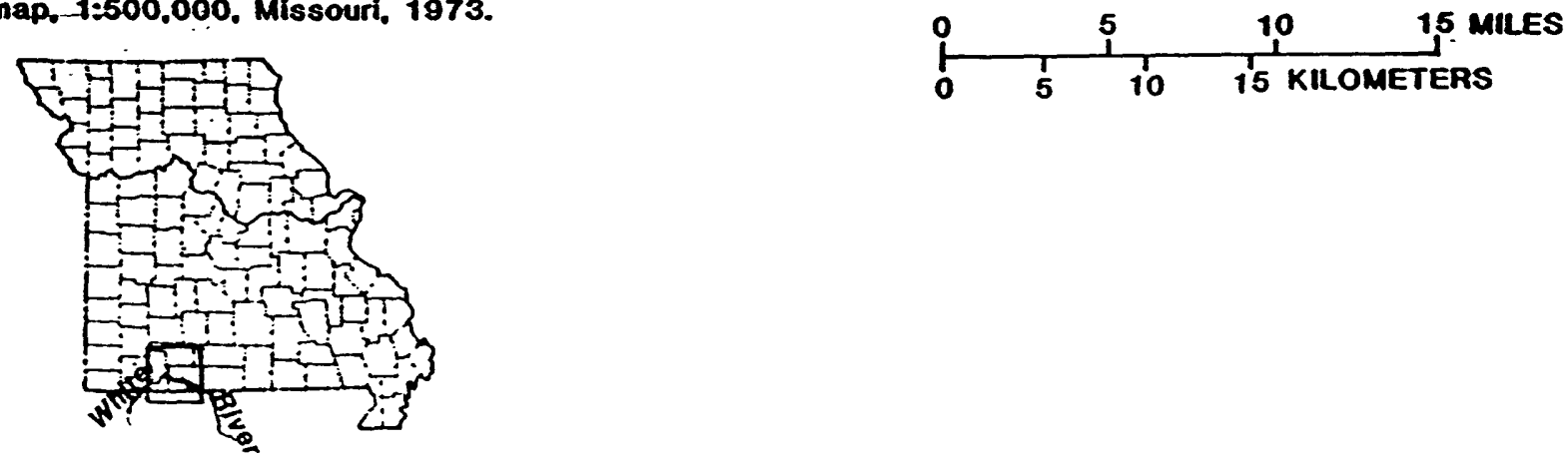

Figure 1.--Location of the study area. 
vicinity of Branson. However, data collection efforts have been concentrated near Branson. The purpose of this interim report is to present water-level, water-quality, and water-use data collected during the first year of the study.

\section{GEOHYDROLOGIC DESCRIPTION OF THE STUDY AREA}

The study area includes most of Taney County and Stone County, the southern one-half of Christian County, and a small part of northem Arkansas. The deeply entrenched White River, a primary discharge area for regional ground-water flow in southern Missouri and northern Arkansas, flows eastward through the study area. The river flows on Ordovician bedrock, primarily the Cotter and Jefferson City Dolomites. Upland areas north and south of the river generally are capped by Mississippian cherty limestone, usually represented by the Burlington and Keokuk Limestones.

Geohydrologic units in the Branson area previously were identified and mapped as part of a regional study of the Ozark Plateaus aquifer system (Imes and Emmett, in press). The units are defined on the basis of regional geohydrologic properties. Six units are present in the Branson area. From the stratigraphically youngest to oldest, the units are (1) the Springfield Plateau aquifer, (2) the Ozark confining unit, (3) the Ozark aquifer, (4) the St. Francois confining unit, (5) the St. Francois aquifer, and (6) the Basement confining unit. A seventh and stratigraphically higher unit, the Western Interior Plains confining system, is present in a small isolated area located in the northwestern comer of the study area. Thin Quaternary alluvial deposits of small areal extent are present along the larger stream valleys. The relation between geohydrologic units and stratigraphic units within the study area is shown in table 1. The Ozark aquifer is the only aquifer important to this study. Many of the stratigraphically higher geologic formations that form the Ozark aquifer are not present in the area. Within the study area, the uppermost formation of the Ozark aquifer generally is the Cotter Dolomite or Jefferson City Dolomite; however, the Everton Formation, Smithville Formation, and Powell Dolomite also are present and can be the uppermost formation of the aquifer along the southern margins of the study area. The permeability of formations that comprise the Ozark aquifer in the area differ sufficiently enough that the aquifer can be divided into two reasonably distinct zones. The upper, less permeable zone includes the Jefferson City Dolomite and overlying formations of the aquifer, and the lower, more permeable zone includes the four formations of the aquifer that underlie the Jefferson City Dolomite (the Roubidoux Formation, Gasconade Dolomite, Eminence Dolomite, and Potosi Dolomite).

The top of the St. Francois aquifer, the lowermost aquifer in the Ozark Plateaus aquifer system, ranges from about $1,500 \mathrm{ft}$ to $2,000 \mathrm{ft}$ (feet) below land surface. Because of the depth of the St. Francois aquifer and because adequate quantities of ground water for municipal and industrial supply exist in the overlying Ozark aquifer, water-supply wells in the study area are not open to the St. Francois aquifer.

\section{GROUND-WATER LEVELS IN THE OZARK AQUIFER}

Water levels in 77 wells that are open to the Ozark aquifer were measured in June and July 1988, during the peak of the tourist season, and water levels in 25 wells were measured in March 1989, after a decrease in water demand during the winter months (fig. 2). The water-level data are presented in table 2 with the results of water-level measurements made during summer 1987 by the Missouri Department of Natural Resources, Division of Geology and Land Survey (Brown, in press) and water levels measured in August 1987 in wells located in Arkansas that are part of data entered into the U.S. Geological Survey Ground-Water Site Inventory file at Little Rock, Arkansas.

A comparison of water levels measured in the same wells during the summers of 1987 and 1988 shows that water levels increased in five wells and decreased in three wells. It is difficult to make meaningful conclusions about the summer 1987 to summer 1988 water-level changes because no water-use data are available to relate changes in water levels to changes in water-use patterns. Because many measurements were made in different wells, a more accurate assessment of whether long-term water-level declines are occurring will be available later from interpretations of potentiometric maps that include all 
Table 1.--Generalized correlation of stratigraphic to geohydrologic units in the Branson area

\begin{tabular}{|c|c|c|c|}
\hline $\begin{array}{l}\text { Regional } \\
\text { geohydrologic } \\
\text { system }\end{array}$ & $\begin{array}{c}\text { Regional } \\
\text { geohydrologic } \\
\text { unit }\end{array}$ & Principal stratigraphic unit(s) & $\begin{array}{l}\text { Time- } \\
\text { stratigraphic } \\
\text { unit }\end{array}$ \\
\hline \multirow{5}{*}{$\begin{array}{l}\text { Ozark } \\
\text { Plateaus } \\
\text { Aquifer } \\
\text { System }\end{array}$} & $\begin{array}{l}\text { Springfield } \\
\text { Plateau } \\
\text { aquifer }\end{array}$ & $\begin{array}{l}\text { St. Louis Limestone, Salem Limestone, } \\
\text { Warsaw Limestone, Boone Formation, } \\
\text { St. Joe Limestone Member of Boone } \\
\text { Formation, Keokuk Limestone, } \\
\text { Burlington Limestone, Elsey Formation, } \\
\text { Reeds Spring Formation, and } \\
\text { Pierson Formation }\end{array}$ & Mississippian \\
\hline & $\begin{array}{c}\text { Ozark } \\
\text { confining } \\
\text { unit }\end{array}$ & $\begin{array}{l}\text { Northview Shale, Sedalia } \\
\text { Limestone, Compton } \\
\text { Limestone, and Chattanooga } \\
\text { Shale }\end{array}$ & $\begin{array}{c}\text { Lower } \\
\text { Mississippian } \\
\text { and } \\
\text { Upper } \\
\text { Devonian }\end{array}$ \\
\hline & $\begin{array}{l}\text { Ozark } \\
\text { aquifer }\end{array}$ & $\begin{array}{l}\text { Clifty Limestone, Penters Chert, } \\
\text { Lafferty Limestone, St. Clair } \\
\text { Limestone, Brassfield Limestone, } \\
\text { Cason Shale, Fernvale Limestone, } \\
\text { Kimmswick Limestone, Plattin } \\
\text { Limestone, Joachim Dolomite, St. } \\
\text { Peter Sandstone, Everton } \\
\text { Formation, Smithville Formation, } \\
\text { Powell Dolomite, Cotter Dolomite, } \\
\text { Jefferson City Dolomite, } \\
\text { Roubidoux Formation, Gasconade } \\
\text { Dolomite, Van Buren Formation, } \\
\text { Gunter Sandstone Member of Van } \\
\text { Buren Formation, Eminence } \\
\text { Dolomite, and Potosi Dolomite }\end{array}$ & $\begin{array}{l}\text { Middle } \\
\text { Devonian } \\
\text { through } \\
\text { Uppermost } \\
\text { Cambrian }\end{array}$ \\
\hline & $\begin{array}{l}\text { St. Francois } \\
\text { confining } \\
\text { unit }\end{array}$ & $\begin{array}{c}\text { Doe Run Dolomite, Derby Dolomite, } \\
\text { and Davis Formation }\end{array}$ & $\begin{array}{l}\text { Upper } \\
\text { Cambrian }\end{array}$ \\
\hline & $\begin{array}{l}\text { St. Francois } \\
\text { aquifer }\end{array}$ & $\begin{array}{l}\text { Bonneterre Dolomite, Reagan } \\
\text { Sandstone, and Lamotte Sandstone }\end{array}$ & $\begin{array}{l}\text { Upper } \\
\text { Cambrian }\end{array}$ \\
\hline & $\begin{array}{l}\text { Basement } \\
\text { confining } \\
\text { unit }\end{array}$ & $\begin{array}{l}\text { Mostly igneous and metamorphic } \\
\text { rock }\end{array}$ & Precambrian \\
\hline
\end{tabular}




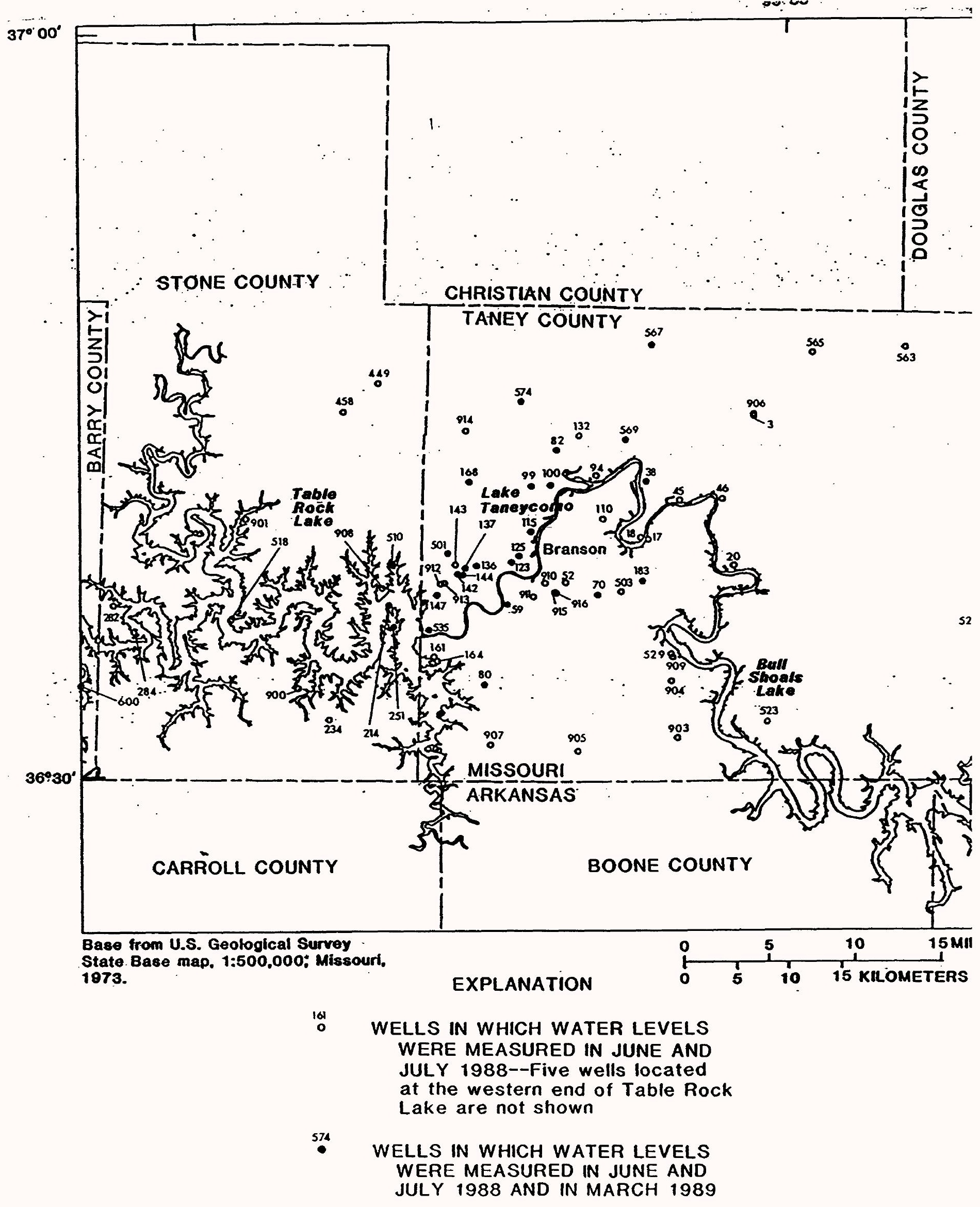

Figure 2.--Location of wells in which water levels were measured in June and July 1988 and in March 1989. 


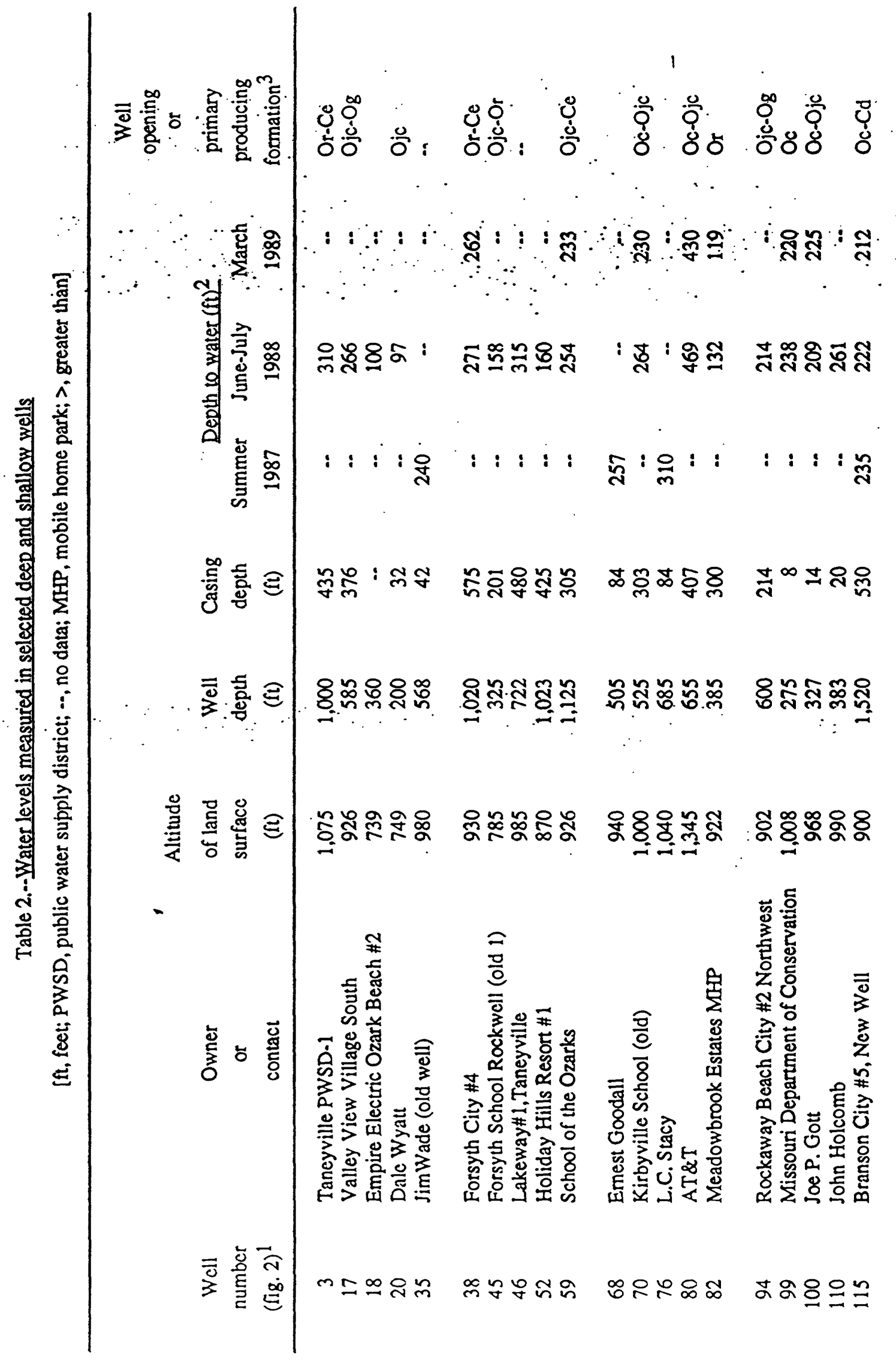




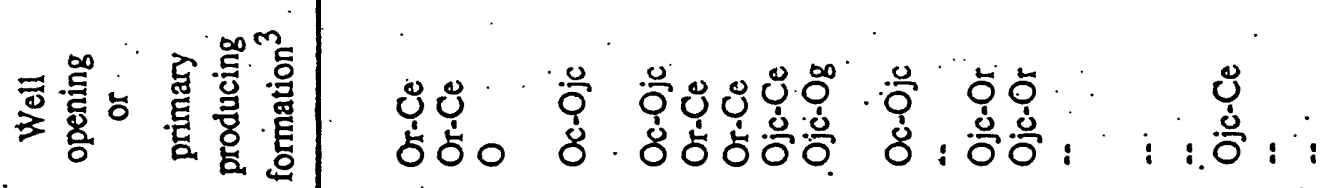

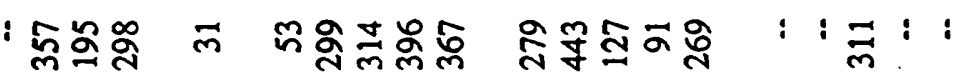

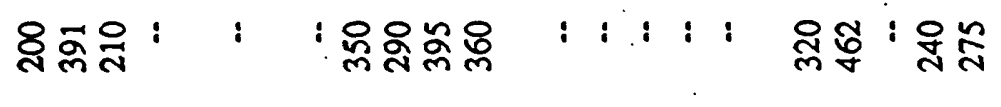

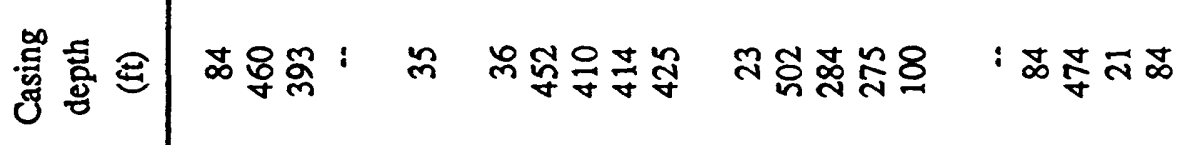

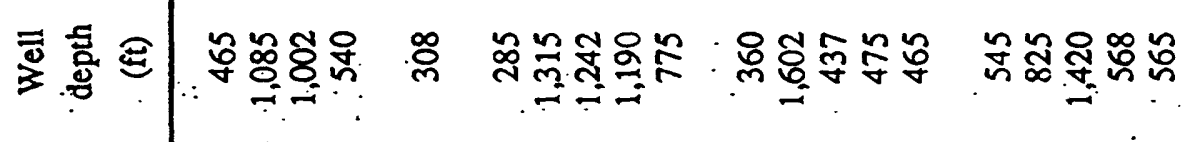

党莺莺

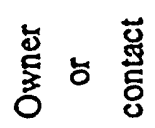

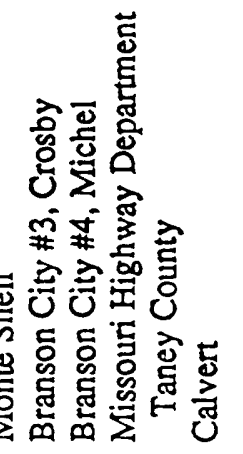

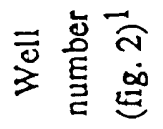

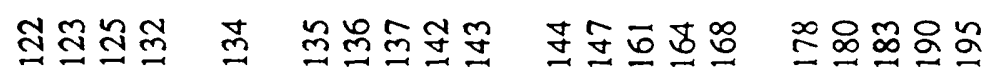




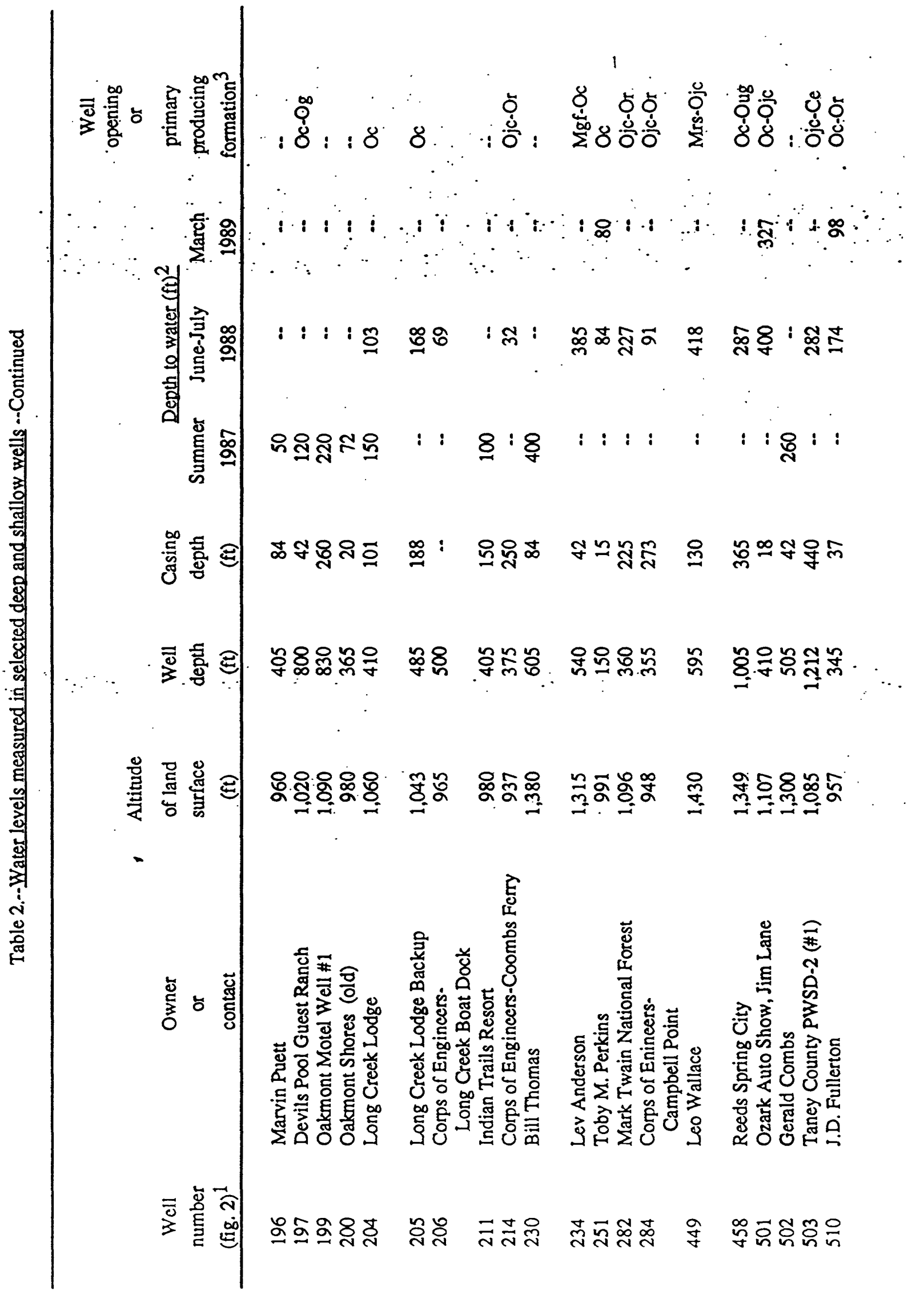




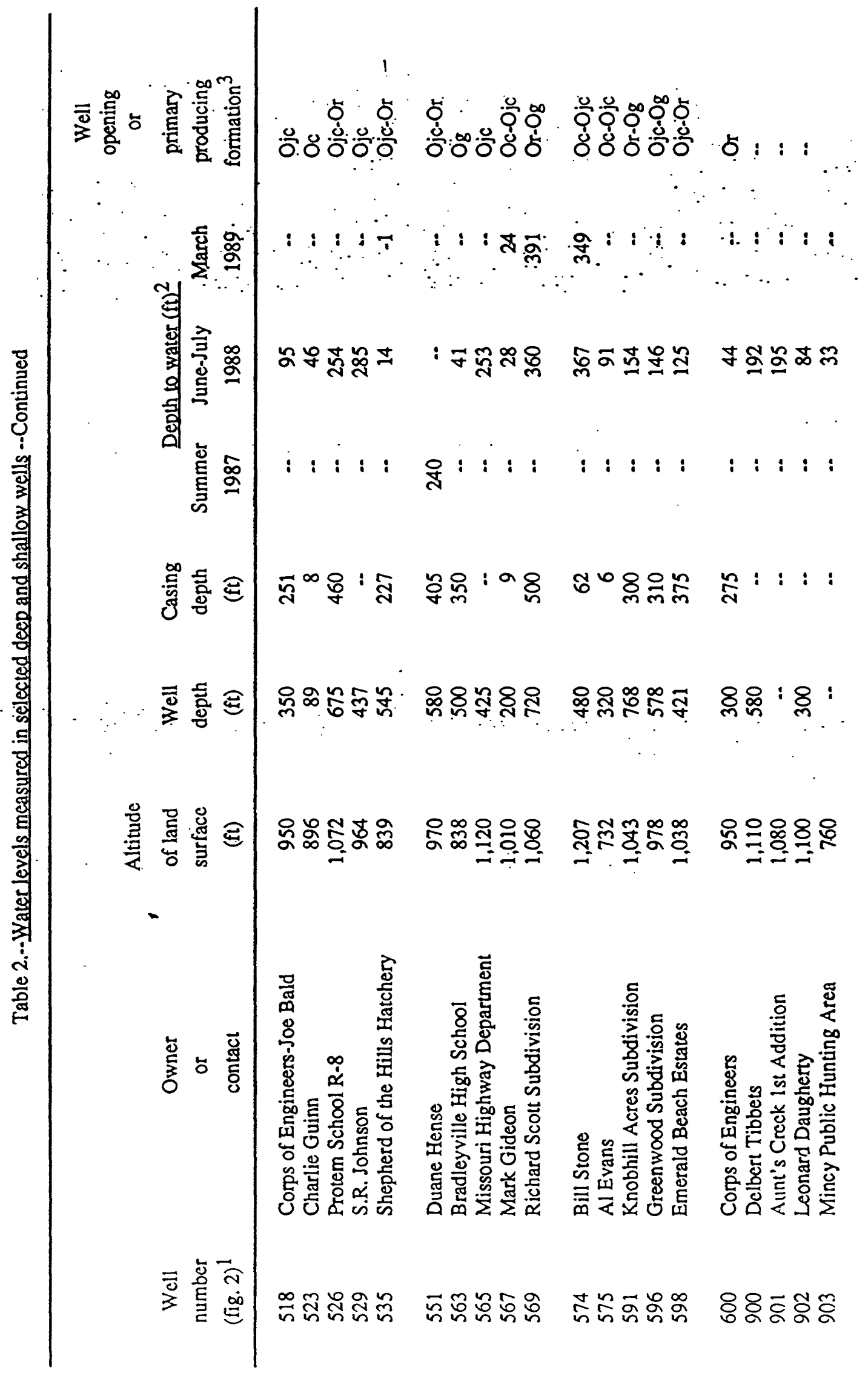




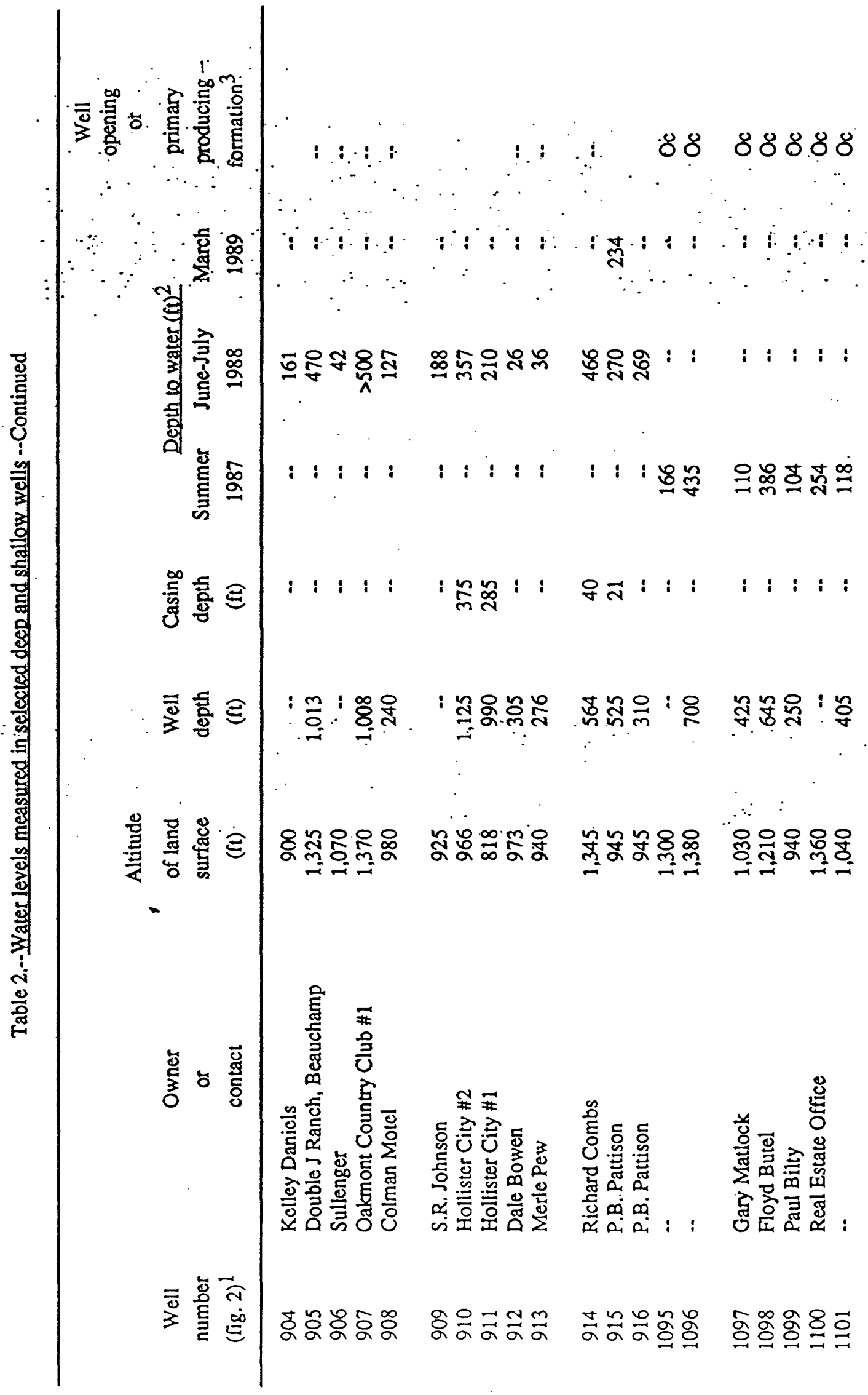




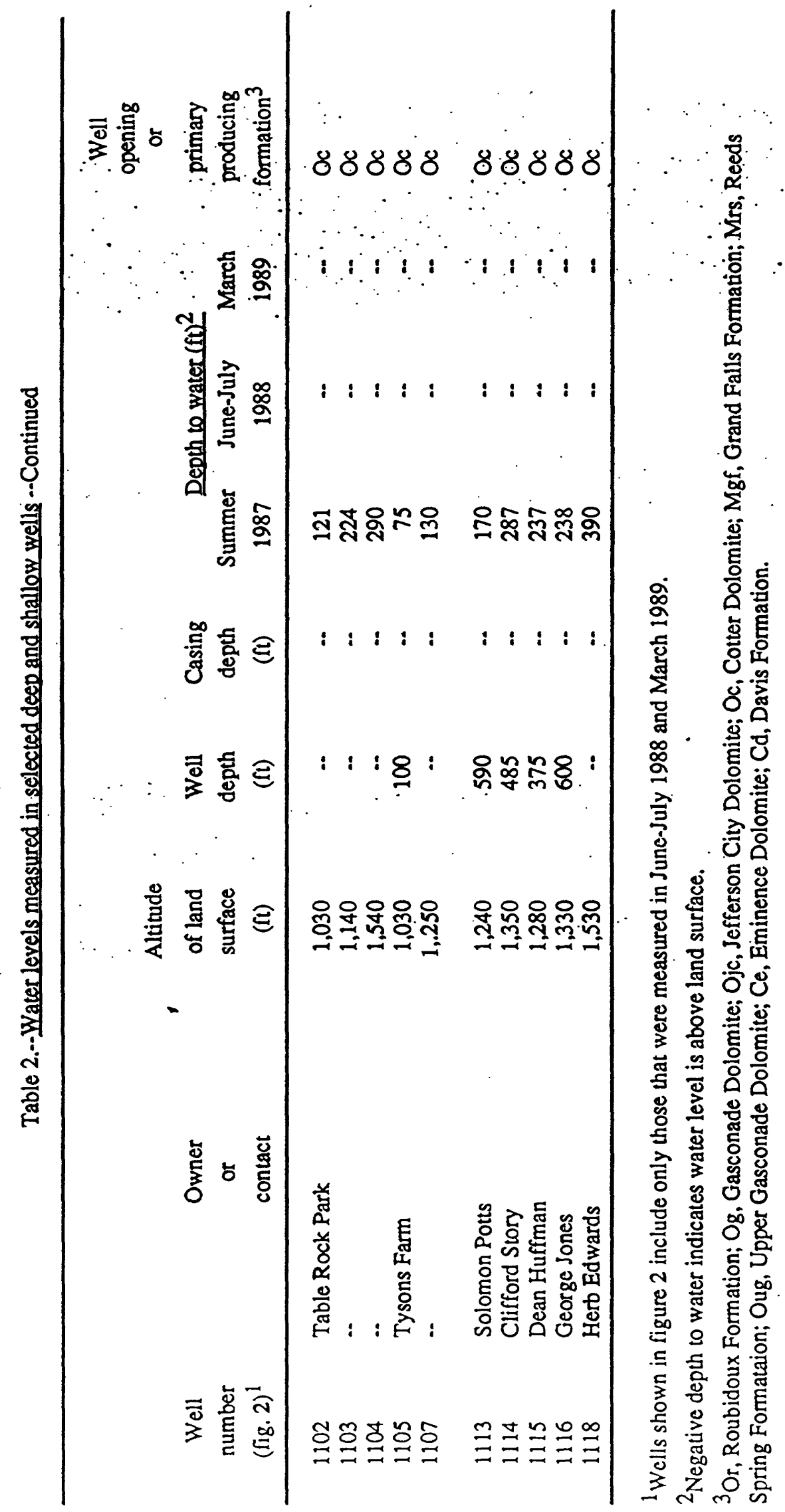


measured water levels. A similar comparison of water levels measured in the summer of 1988 and March 1989 shows water levels increased in 23 wells, decreased in 2 wells, and remained the same in 1 well. Waterlevel increases in the 23 wells ranged from $4 \mathrm{ft}$ to $111 \mathrm{ft}$, with the larger increases occurring in the city of Branson municipal wells.

\section{GROUND-WATER MONITORING}

From the inception of this project, it was determined that several wells in the study area needed to be monitored on a regular basis to provide information on the seasonal fluctuations of water levels in the Ozark aquifer. After completion of a well inventory and the first mass water-level measurements during the summer of 1988, seven wells were selected as suitable candidates for water-level monitoring wells. Permission to measure water levels monthly could be obtained for only two deep wells; well 59 (School of the Ozarks), and well 125 (city of Branson "Michel" well); and one shallow well, well 144 (Gateway Subdivision) (fig. 3). It was not possible to locate and gain permission to use paired shallow and deep wells to monitor hydraulic head differences between the shallower and deeper rocks of the Ozark aquifer. The city of Branson began monitoring water levels in the three wells in late September 1988, but soon discontinued wells 59 and 144 because of time and personnel constraints. A hydrograph of water-level data for well 125 (fig. 4) shows water levels rising $21 \mathrm{ft}$ from late September 1988 to early December 1988 and remaining relatively stable from December 1988 through March 1989.

\section{GROUND-WATER QUALITY IN SELECTED WELLS}

To address concerns about the quality of water in the Ozark aquifer near Branson, water-quality samples were collected in 34 wells, located primarily between Branson and Forsyth (fig. 5). The specific conductance of each sample and a count of fecal coliform bacteria in $25 \mathrm{ml}$ (milliliters) and $100 \mathrm{ml}$ of sample was determined in the field. Laboratory analyses for chloride, total nitrite plus nitrate $[\mathrm{mg} / \mathrm{L}$ (milligrams per liter) of nitrogen], and total nitrite $(\mathrm{mg} / \mathrm{L}$ of nitrogen) were made for each sample, and total nitrate ( $\mathrm{mg} / \mathrm{L}$ of nitrogen) was calculated from results of the laboratory analyses (table 3). Analysis for these inorganic species was made because they are indicators of contamination from sewage effluent, a primary concern in the area. Specific conductance of the samples ranged from 347 to $841 \mu \mathrm{S} / \mathrm{cm}$ (microsiemens per centimeter at $25^{\circ} \mathrm{Celsius),} \mathrm{and} \mathrm{no} \mathrm{samples} \mathrm{contained} \mathrm{fecal} \mathrm{coliform.} \mathrm{Chloride} \mathrm{concentrations} \mathrm{in} \mathrm{samples} \mathrm{from}$ five wells exceeded the detection limit of $5 \mathrm{mg} / \mathrm{L}$. Water from well 101 had the largest chloride concentration $(81 \mathrm{mg} / \mathrm{L})$; however, this concentration is considerably less than the Missouri Department of Natural Resources (1987) recommended maximum concentration of $250 \mathrm{mg} / \mathrm{L}$. Nitrate concentrations in 27 wells were below the detection limit, 1 sample container was damaged in transit and the sample was lost, and 6 samples contained measurable concentrations of nitrite plus nitrate or nitrite. The maximum concentration of nitrate determined for the samples was $0.6 \mathrm{mg} / \mathrm{L}$, well below the Missouri Department of Natural Resources (1987) recommended maximum concentration of $10 \mathrm{mg} / \mathrm{L}$.

In addition to analyzing ground-water samples for inorganic species, samples from 5 wells (fig. 5) were analyzed for selected volatile organic compounds. None of the analyses detected the presence of any of the 33 volatile organic compounds in excess of the detection limits for the compounds (table 4).

\section{GROUND-WATER USE BY MUNICIPALITIES, PUBLIC WATER-SUPPLY DISTRICTS, AND SELECTED BUSINESSES}

Because it is necessary to have accurate water-use data to properly calibrate a ground-water flow model, the primary ground-water users (fig. 6) were contacted in September 1988 and were requested to measure their water use monthly for the next one and one-half years and report the water-use data each month to the U.S. Geological Survey. Generally, response to this request was favorable, although in practice an occasional reminder is necessary to actually obtain the data. Monthly water-use information collected to date is listed in table 5 . 


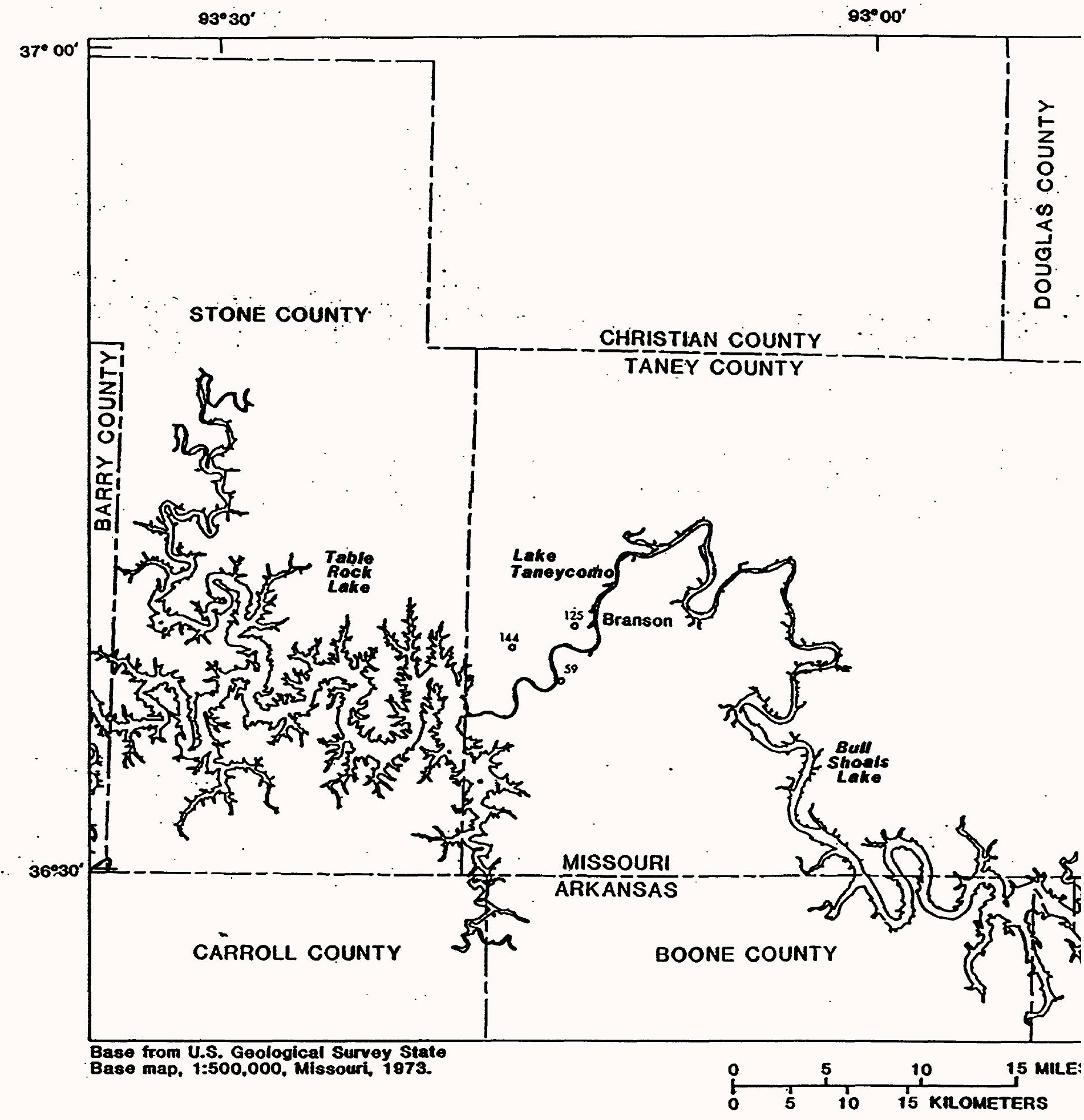

EXPLANATION

I\%4 WATER-LEVEL MONITORING WELL

Figure 3.--Location of water-level monitoring wells. 


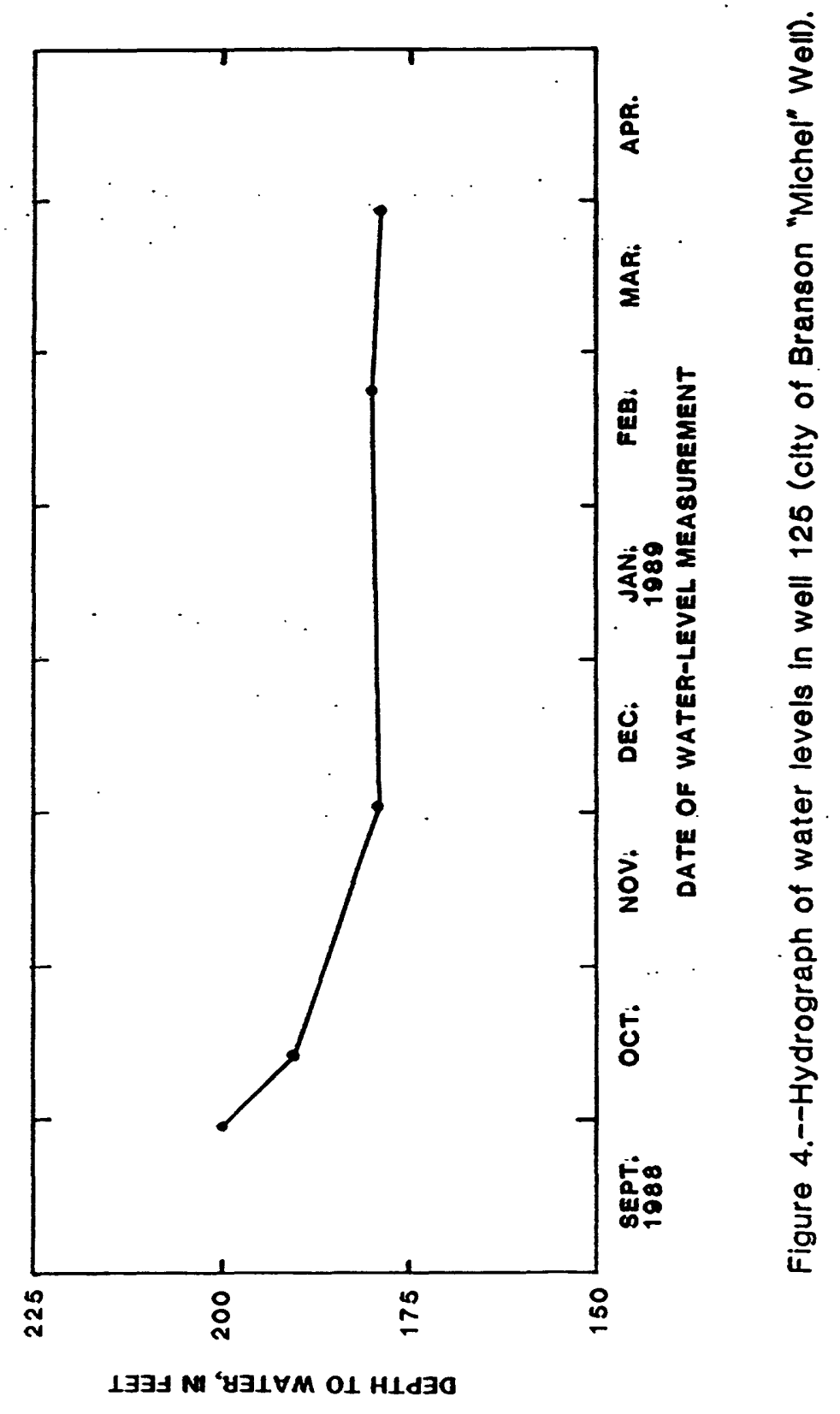




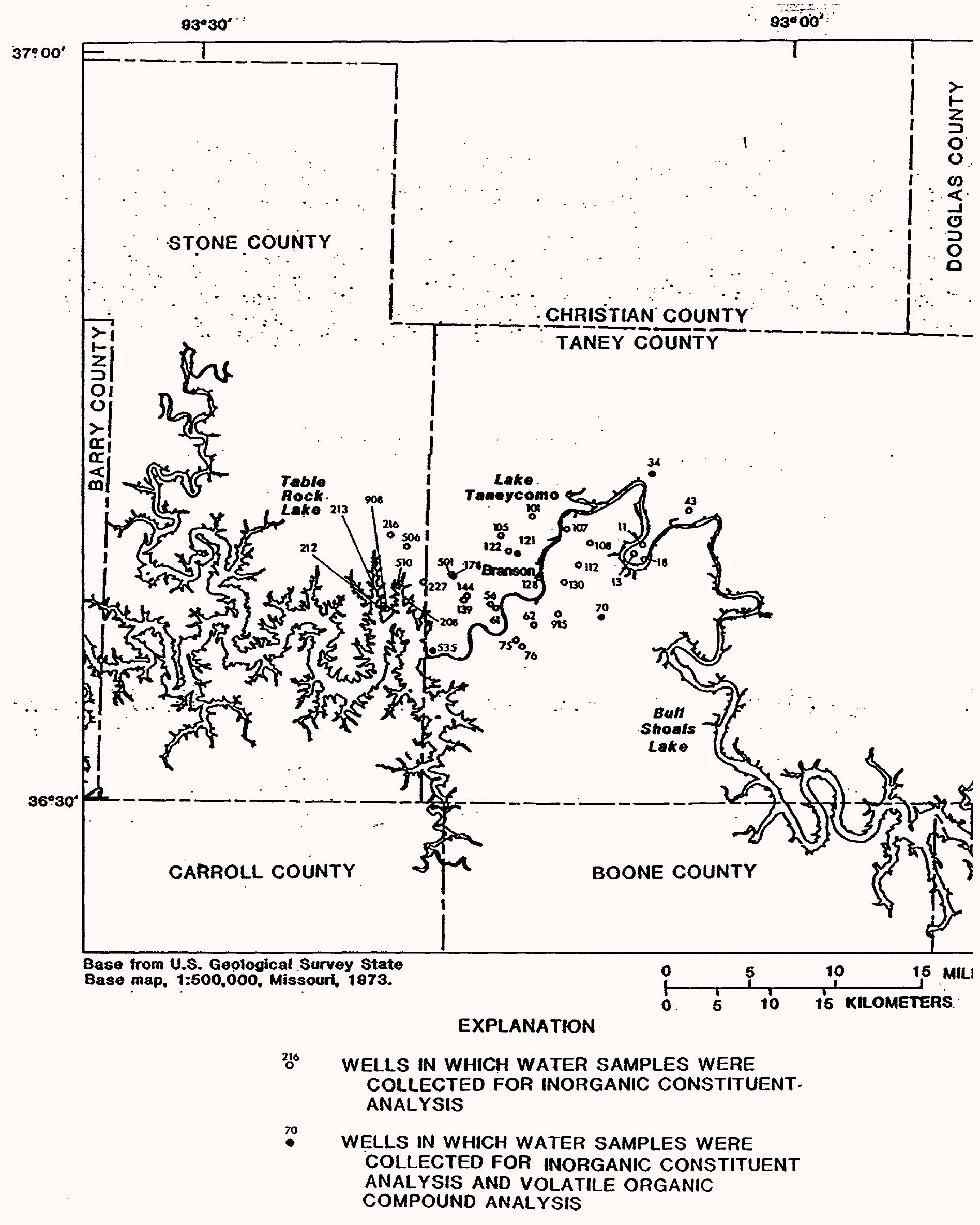

Figure 5.--Location of wells in which water-quality samples were collected and analyzed for selected inorganic constituents and volatile organic compounds. 


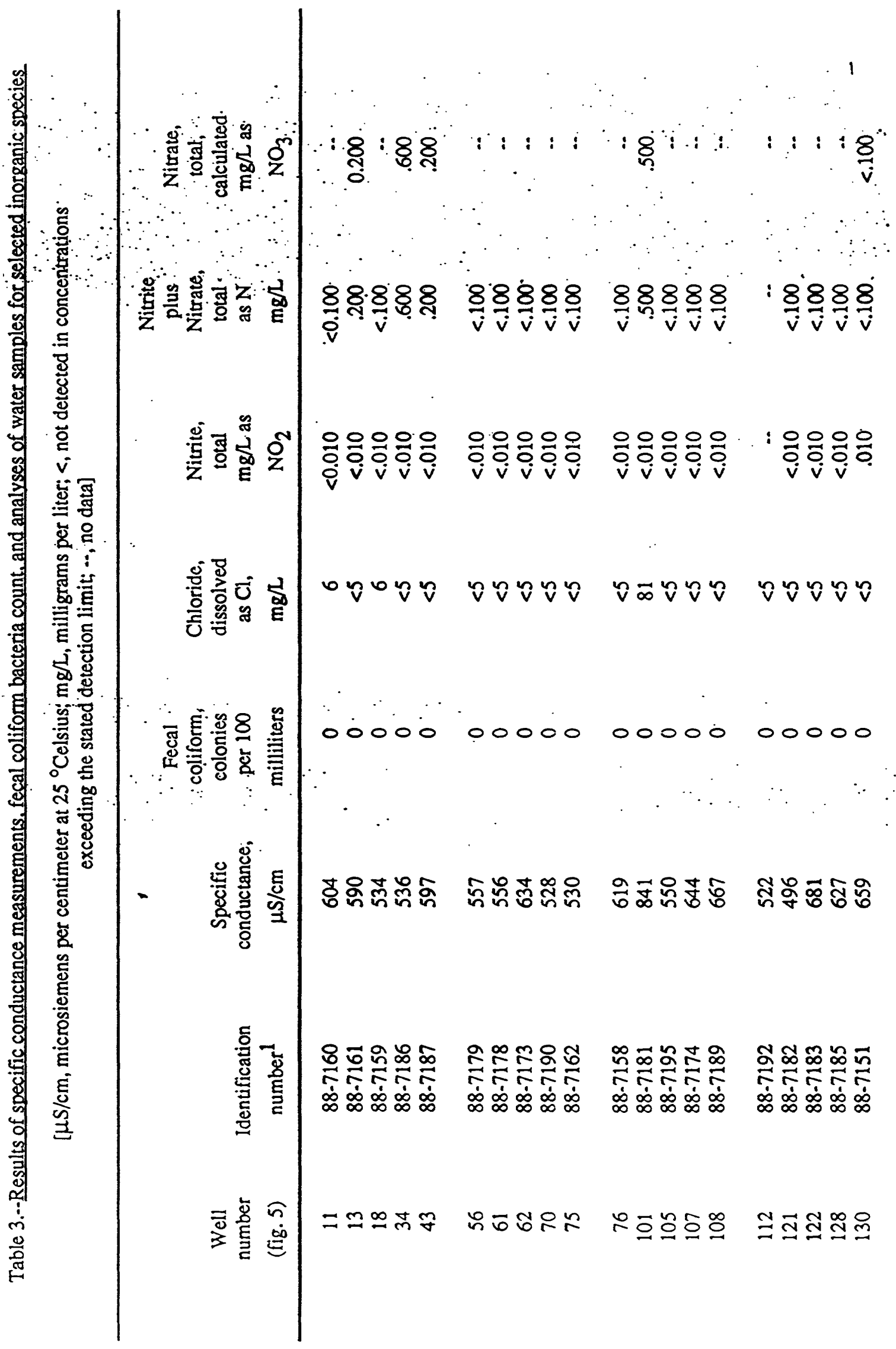




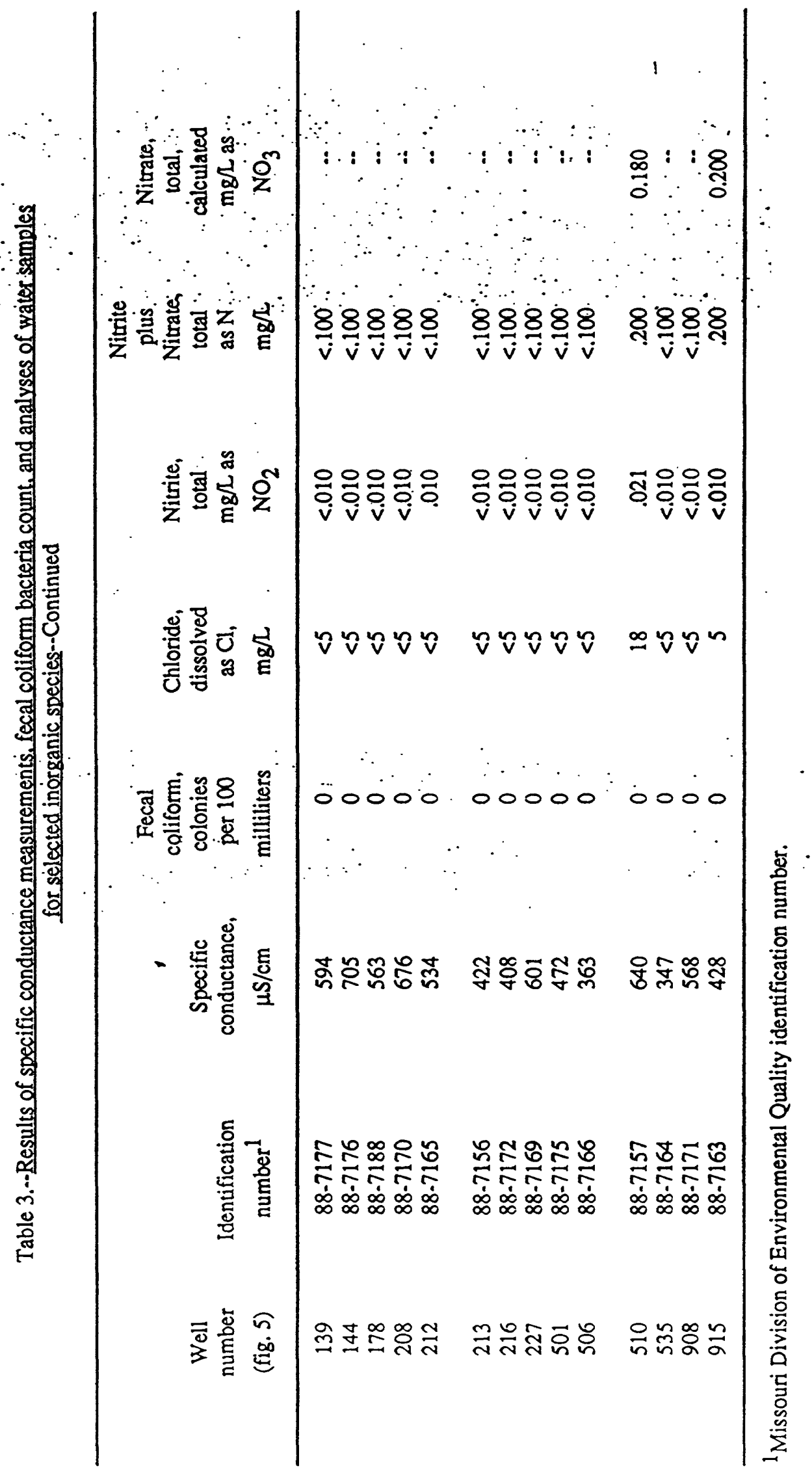




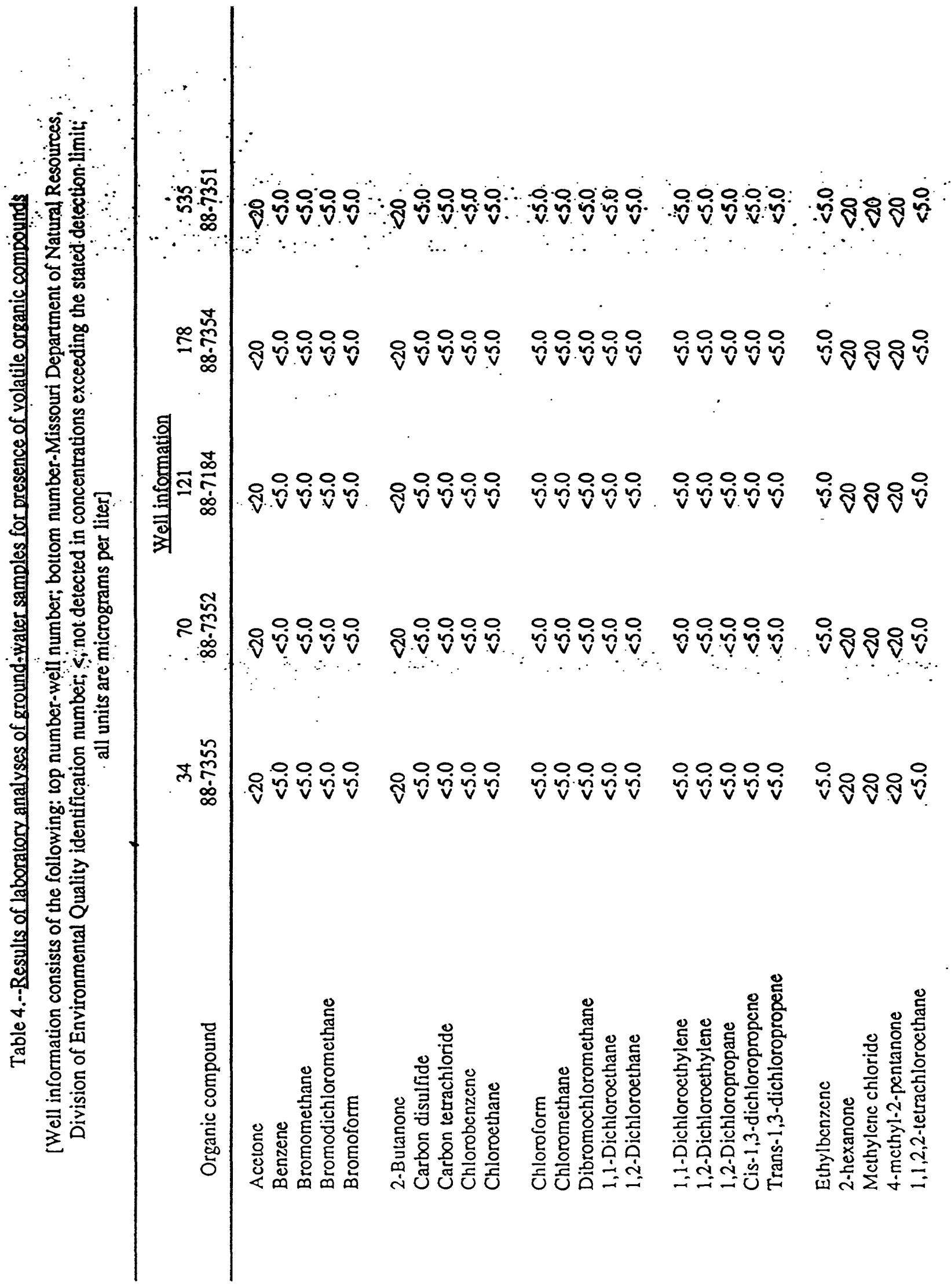




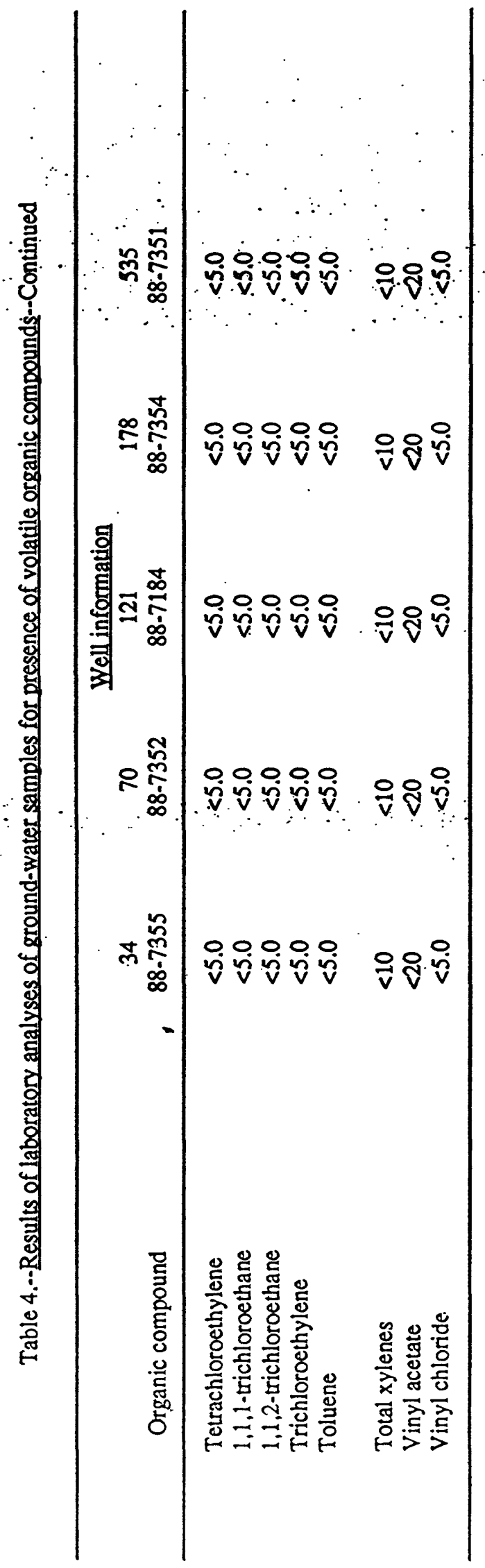




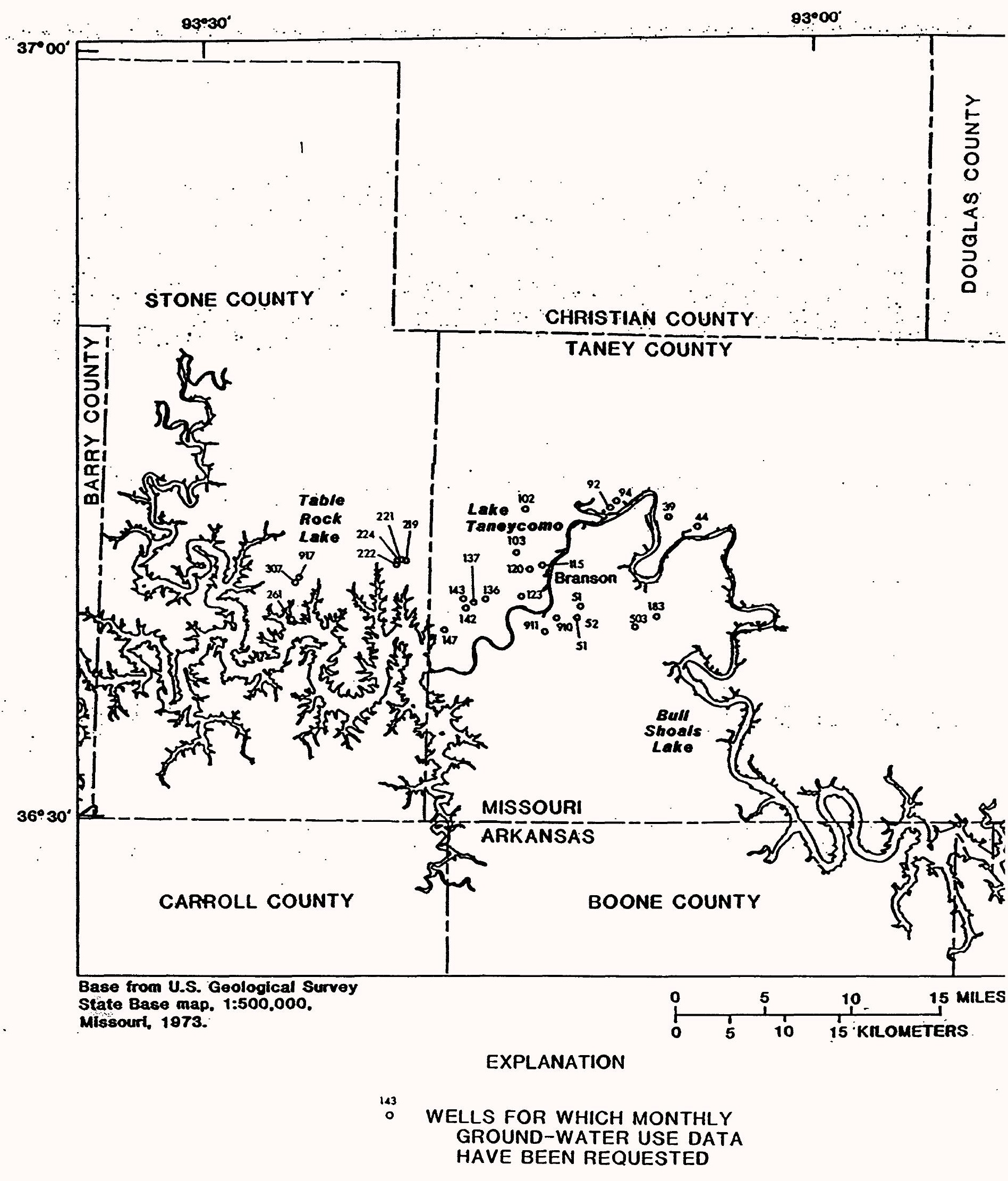

Figure 6.--Location of wells for which monthly ground-water use data have been requested. 


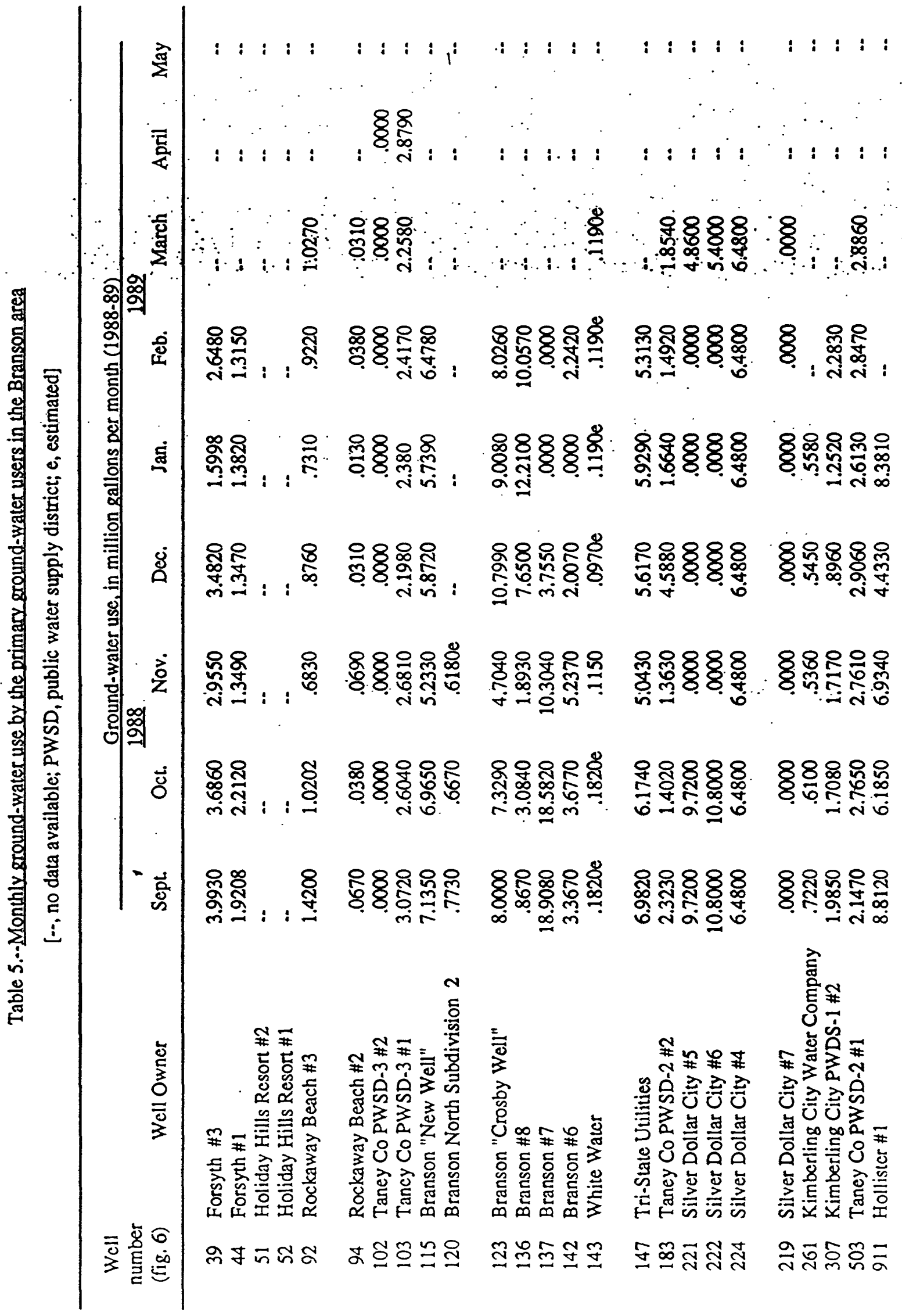




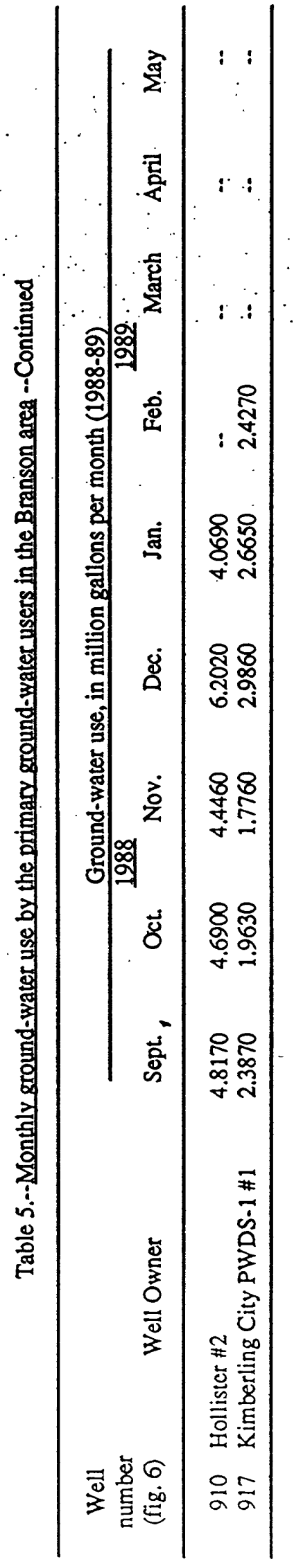




\section{GROUND-WATER FLOW MODEL DEVELOPMENT}

A three-dimensional finite-difference model of ground-water flow in the upper and lower zones of the Ozark aquifer has been designed and is being constructed. The U.S. Geological Survey modular model developed by McDonald and Harbaugh (1984) is being used in this analysis. The variable grid model contains 54 rows by 55 columns centered in the Branson area with cell sizes ranging from 2 mi by 2 mi near the corners of the model to $0.5 \mathrm{mi}$ by $0.5 \mathrm{mi}$ near the center of the model. Computerized data bases of geohydrologic and water-use information have been created and are being used to prepare contour maps of the altitude of the top of each important geohydrologic unit and potentiometric surface maps for each zone of the Ozark aquifer. The contour maps will be used to generate aquifer thickness data, saturated rock thickness data, and related information necessary for calibration of the flow model.

\section{SUMMARY AND FOCUS OF FUTURE WORK}

Measurements of water levels made during this study show substantial seasonal changes. Comparison of changes in water levels measured in the same wells from the summer of 1987 to the summer of 1988 cannot be used to accurately assess whether long-term water level declines are occurring in the area, because water levels in few wells were measured at both times. However, interpretative potentiometric maps based on all measured water levels during the summers of 1987, 1988, and 1989 should provide sufficient data to make an analysis of water-level trends.

A survey of 34 wells to determine the concentrations of fecal coliform bacteria and inorganic chemicals showed no fecal coliform bacteria present in any well, and no unusually large concentration of inorganic constituents. Chloride and nitrate concentrations in all water samples were less than the Missouri Department of Natural Resources recommended maximum concentrations. An analysis of 5 water samples for a suite of 33 volatile organic compounds failed to detect the presence of any of the compounds.

Water-level measurements will be made during the summer 1989 tourist season, and the monthly water-use data will continue to be updated. The remainder of the project time will be spent analyzing the collected data, completing the construction of the ground-water flow model, and calibrating the model to the available hydrologic data. Upon completion of the data analysis and model calibration, one or two simulations will be prepared to represent the potential effects of continued ground-water withdrawals in the Branson area. Finally, a comprehensive report will be prepared that presents the results of the data analysis and model simulations. 


\section{REFERENCES CITED}

Brown, J.C., Jr., in press, Groundwater assessment of the Lake Taneycomo area, Taney County, Missouri: Missouri Department of Natural Resources, Division of Geology and land Survey, unpublished manuscript.

Imes, J.L., and Emmett, L.F., in press, Geohydrology of the Ozark Plateaus aquifer system in parts of Missouri, Arkansas, Oklahoma, and Kansas: U.S. Geological Survey Professional Paper 1414-F.

McDonald, M.G., and Harbaugh, A.W., 1984, A modular three-dimensional finite- difference ground-water flow model: U.S. Geological Survey Open-File Report 83-875, 528 p.

Missouri Department of Natural Resources, 1985, Missouri water-quality standards: Division 20-10CSR, 207.031 . 